\title{
Text, speech product, phrase: on the interpretation of various linguistic terms
}

\author{
Филиппов Константин Анатольевич
}

Санкт-Петербургский государственный университет (СПбГУ), Санкт-Петербург, Россия

\section{Текст, речевое произведение, фраза: О различной интерпретации лингвистических терминов}

\author{
Filippov Konstantin Anatolievich
}

Saint Petersburg State University (SPSU), St. Petersburg, Russia

\begin{abstract}
Аннотация
В статье на материале словарных дефиниций проводится сопоставительный анализ различных трактовок терминов текст, речевое произведение, фраза. Наибольшее число разногласий наблюдается в интерпретации термина фраза. При наличии значительных расхождений в интерпретации этого термина решение данной терминологической проблемы связано с использованием дериватов с корневой морфемой фраз- в терминах со значением «сверх объема предложения», например, рус. сверхфразовое единство, нем. transphrastische Grammatik, англ. Transphrastic linguistics и т.п. В интерпретации таких дериватов не обнаруживается каких-либо расхождений в работах отечественных и зарубежных лингвистов.
\end{abstract}

\begin{abstract}
In this article a comparative analysis of different interpretations of the terms text, speech product, phrase is carried out on the material of dictionary definitions.Most notable is the difference between existing approaches to the interpretation of the term phrase.With such a divergence of views on this concept in Russian and foreign linguistics a solution ofthis terminological issue is associated with one of the derivatives from the root morpheme phras-,in terms with a meaning 'greater than a sentence' for example, in russ. sverhfrazovoje edinstvo, dt. transphrastische Grammatik, engl. transphrastic linguistics, etc. Practice does not reveal any significant differences between Russian and foreign linguists in the interpretation of these derivatives.
\end{abstract}

Ключевые слова:
терминология, трамматика,
произведение, фраза.


Keywords: grammar, terminology, text, speech product, phrase.

1. The concepts of text, speech product, phrase refer to the basic terminological apparatus of linguistic analysis of the text. Over time, the value of certain terminological entities undergoes correction that occurs for various reasons, for example, a change of the author's position. In this article a comparative analysis of different interpretations of the terms text, speech product, phrase is carried out on the material of dictionary definitions, in accordance with the fundamental principles of modern text linguistics.

2. In O. Akhmanova's "Dictionary of linguistic terms" (2016) we find direct evidence of the interrelation between the concepts of text and speech product: «TEXT...1. Same as the product of speech. 2. The product of speech, recorded in the writing ...» [Akhmanova, p. 470]. The product of speech O. Akhmanova understands as «actually expressed (written, etc.) sentence or a set of sentences (including a piece of oral or written speech of any length, up to a whole literary work, etc.), which is able, in particular, to serve as a material for observation of language facts»[Ibid., p. 365]. Thus, the first two meanings of the term text include a broad and a narrow approach to this lexical unit: the first sense equaling the text to a product of speech (or the speech itself), and the second one being essentially a customary one, because it is this interpretation of the text as a speech product recorded in writing that is supported by definitions in modern dictionaries of the Russian language. The study of text as an object of linguistic research has not lost its appeal at the beginning of the new millennium. Among the current trends of modern text linguistics are traditional issues of organization and functioning of text structures, as well as the problem of identifying the role of communication participants' different systems of knowledge in the process of text production and text perception etc.

3 . When investigating other concepts related to the nature and structure of speech products, one can come across interesting contrasts of different views on the interpretation of speech phenomena. Thus, the term phrase gets the following interpretation in Russian linguistics: «PHRASE... 1. The smallest independent unit of speech, communication unit actualized. 2. (Partial phrase). Into national unity, the basic unit of intonation. This unity is allocated as a segment of the speech between two pauses, following one after the other» [Akhmanova, p. 502].These definitions resemble A. Peshkovsky's observations atfeatures of Russian syntax, namely his interpretation of the concept of a complex whole. Whereas the O. Akhmanova treats complex whole as «the same as the complex sentence» [Ibid., p. 432], for A. Peshkovsky a complex whole is «a combination of sentences connected by conjunctions, connectives or combining syntactic pauses and not disconnected by separating syntactic pauses» [Peshkovski, p. 410].

4. In the words of A. Peshkovsky, speech consists of a completely chaotic change of single sentences and complex wholes, the basic unit of intonation being neither a sentence, nor a complex whole, but a certain value which is times grammatically complex, times simple. It is this value A. Peshkovski suggested to call an intonation unity or simply a phrase. By phrase he thus understood «every speech segment from one separating pause to another, no matter how many sentences it consists of» [Ibid]. In this issue we see a significant divergence from the opinion of O. Akhmanova who restricts a complex 
whole to the limits of a complex sentence.

5. Thus, in his characterization of a complex whole A. Peshkovski has approached the problem of the systematic description of constitutive features of the text. His argument is based on the understanding that speech as an organized a linear sequence of linguistic units is built according to certain rules, valid not only within a single sentence, but also within larger speech segments. For O. Akhmanova such an approach to the description of whole speech products probably seemed premature, especially if we take into account her words that a speech product, which is understood as «a sentence or set of sentences» as a «segment of oral or written speech of any length», can at most «serve as material for observation of the facts of language».

6. The most precise definition of the term phrase can be found in the «Linguistic Encyclopedic Dictionary»: «PHRASE ... 1) the basic unit of speech that expresses a complete thought; a semantic unity, the integrity of which is created by means of intonation (combines phrasal intonation of a particular type and pauses that separate this sentence from the next), as well as a certain syntactic structure ...; 2) in a non-strict terminological usage - the same as a sentence; 3) any intonation and semantic unity, bounded on two sides by pauses»» [Linguistic Encyclopedic Dictionary, p. 558-559].

7. In modern foreign theory, we can find significant differences from the fore cited treatments. Linguistic characteristics of the concept of phrase is usually associated with the name of L. Bloomfield, who used the term in his syntactical description of the concept known as Immediate Constituent Analysis. Cf.: «A free form which consists entirely of two or more lesser free form, as, for instance, poor John, or
John run away or yes, sir, is a phrase. A free form which is not a phrase, is a word. A word, then, is a free form, is does not consist entirely of (two or more) lesser free forms; in brief, a word is a minimum free form» [Bloomfield, p. 178]. This position is established in both scientific and educational publications. Although the MacMillan dictionary has no reference to L. Bloomfield, the dictionary still treats a phrase as not extending beyond the scope of a sentence. Cf.: «a group of words that form a unit within a CLAUSE (= a group of words containing a subject and a verb): the ways in which words combine to form phrases and sentences» [Macmillan English Dictionary, p. 1062]).

8. The German authors fully share the fore cited views. V. Ulrich defines the term Phrase as «syntaktisch zusammengehörige Wortfolge (ohne finite Verbform); Wortgruppe oder Satzteil von relativer Selbständigkeit in IC-Analyse von Sätzen ») [Ulrich, S. 217]. This position is confirmed by one of the latest fundamental German publications on linguistics: «Eine Phrase ist eine Gruppe von zumeist beieinanderstehenden Wortformen; die als Ganzes eine bestimmte wortartliche Prägung und bestimmte grammatische Merkmale zeigt» [Sprachwissenschaft, S. 141]. Accordingly, by dividing of a sentence into smaller pieces following categories are formed: Adjektivphrase, Nominalphrase, Präpositionalphrase, Verbalphrase [Ibid., S. 142].

9. With such a divergence of views on the concept of phrase in Russian and foreign linguistics it is difficult to expect any compromise in resolving this terminological issue. However, such a solution is available, and it is associated with one of the derivatives from the root morpheme phras-. This morpheme is a supporting element for the creation of terms, the proper meaning of which is 
«over the volume of sentence», for example, in russ. sverhfrazovoje edinstvo, dt. transphrastische Grammatik, eng. transphrastic linguistics, etc. Practice does not reveal any significant differences between Russian and foreign linguists in the interpretation of these derivatives.

\section{Literature}

Akhmanova O.S. Slovar lingvisticheskih terminov (Dictionary of linguistic terms). - M.: Book House "LIBROKOM", 2016. - 576 p.

Bloomfield L. Language. - London: George Allen \& Unmin Ltd., 1933. $566 \mathrm{pp}$.

Lingvisticheskiy entsiklopedicheskiy slovar (Linguistic encyclopaedic dictionary) / Ch. Ed. V.N. Yartseva. M.: Soviet Encyclopedia, 1990. - 685 p.

Macmillan English Dictionary: for advanced learners: International Student Edition. - London: Macmillan, 2002. - 1692 pp.

Peshkovski A.M. Russkiy sintaksis v nauchnom osveschenii (Russian syntax in a scientific light). -6 th ed. - M.: Uchpedgiz, 1938. - 450 p.

Sprachwissenschaft. Grammatik Interaktion - Kognition / Hrsg. v. P. Auer. - Stuttgart; Weimar: Verlag J. B. Metzler, 2013. - 465 S.

Ulrich $W$. Wörterbuch Linguistische Grundbegriffe. - Berlin; Stuttgart: Gebrüder Borntraeger Verlagsbuchhandlung, 2002. - 351 S. 